Article

\title{
Optimization of Coal Washery Tailings by Flotation Process
}

\author{
Changliang Shi ${ }^{1,2,3}$, Gan Cheng ${ }^{1,2,3, *}$ and Shengnan Wang ${ }^{1}$ \\ 1 College of Chemistry and Chemical Engineering, Henan Polytechnic University, Jiaozuo 454000, China; \\ shichangliang@hpu.edu.cn (C.S.); wangsn2015@yeah.net (S.W.) \\ 2 Synergism Innovative Center of Coal Safety Production in Henan Province, Henan Polytechnic University, \\ Jiaozuo 454000, China \\ 3 Henan Key Laboratory of Coal Green Transformation, Henan Polytechnic University, Jiaozuo 454000, China \\ * Correspondence: chenggan464@126.com; Tel.: +03913986812
}

Received: 22 August 2019; Accepted: 14 October 2019; Published: 17 October 2019

check for updates

\begin{abstract}
Flotation tailings are by-products of coal preparation plants, which do not only occupy cultivated land but also cause pollution. The high ash content and low calorific value of tailings limit their applications. Deashing is the precondition for the reutilization of flotation tailings. However, it is more difficult to remove ash content from flotation tailings compared with raw coal. Based on the analysis of coal properties, the flotation performance of different collectors was compared in this study. Flotation flows and the mechanism of depressants were explored. The optimized flotation conditions were as follows: pulp concentration of $100 \mathrm{~g} / \mathrm{L}$, inflation rate of $0.25 \mathrm{~m}^{3} /\left(\mathrm{m}^{2} \cdot \mathrm{min}\right)$, collector (C4) dosage of $300 \mathrm{~g} / \mathrm{t}$, frother dosage of $500 \mathrm{~g} / \mathrm{t}$, and revolving speed of $2200 \mathrm{rpm}$. The ash content of clean coal was also reduced by adding a depressant. The flotation performance was best when the amount of sodium hexametaphosphate (used as the depressant) was $4 \mathrm{~kg} / \mathrm{t}$; the recovery of clean coal was $71.88 \%$, and the ash content was $10.64 \%$.
\end{abstract}

Keywords: coal washery tailings; flotation; ash reduction; collector

\section{Introduction}

Coal is one the world's most important sources of energy [1,2], and its share in the global fuel and energy balance makes up 25-35\% [3]. Almost $40 \%$ of the global electricity is generated using coal. In many countries, this ratio is much higher: over 94\% in Poland, 92\% in South Africa, 77\% in China, and 76\% in Australia. A large amount of tailings is produced during coal processing [4-6]. In 2007 in China, for example, the coal washing rate was 70.20\% [7], flotation feed was estimated as $30 \%$, and tailing coal yield was estimated as 30\%, representing an increase of about 180 million tons in flotation tailing. If these flotation tailings are not effectively treated, they will become one of the main pollution sources in the environment $[8,9]$. Therefore, it is necessary to optimize the recycling of flotation tailings, which will not only improve economic benefits but also save resources and protect the environment [10]. Moreover, it will provide a technical guarantee for exploring the sustainable development of the coal industry.

Different methods for fine coal recovery from washery tailings have been reported in previous studies. Physical [11], physico-chemical, and chemical [12] methods can be applied for the upgrading of coal. Additionally, froth flotation [13,14], oil agglomeration, flocculation [15], and gravity separation methods [16] have been used for cleaning fine coal. Among the different methods, froth flotation is the most common method for removing ash from fine coal. However, due to changes in surface properties $[17,18]$, the recovery of organic matter from flotation tailings is more difficult than that from raw coal. Factors affecting flotation performance were explored by Yaşar et al. [19], who investigated 
the effects of various parameters, including solid ratio, oil dosage, agitation rate and time, slurry $\mathrm{pH}$, amount of washing water, particle size, and oil type on the deashing and desulphurization process. Their results revealed that clean coal with $29.9 \%$ ash and $1.3 \%$ sulfur was obtained from tailings with an initial $54.6 \%$ ash and 3.0\% sulfur. Barraza et al. [20] obtained clean coal with $45 \%$ yield, $92 \%$ combustible recovery, and $20 \%$ ash content using MIBC (methyl isobutyl carbinol) and kerosene as the frother and collector, respectively. Ren et al. [21] used a stirring mill with an 8-mm ball to grind the coal tailings, and the ground coal was classified using a 50-mm small cone angle cyclone. After the tailings classification, the overflow product of the cyclone was floated. Clean coal with $21.82 \%$ recovery and $9.63 \%$ ash content was obtained after flotation of one roughing and two cleanings. Shi [22] compared the performances of classified flotation with conventional flotation, and the findings revealed that the flotability of each particle size was improved with classified flotation. Jiang et al. [23] used a two-stage combination of fast flotation and desliming flotation to obtain a product of $7.8 \%$ ash content and $80 \%$ combustible recovery. Netten and Galvin [24] offered a novel agglomeration technology using an emulsion binder for producing valuable products from fine coal tailings. Li et al. [25] indicated that reverse flotation was an alternative method with the potential for upgrading difficult-to-float coals. Different flotation equipments were used by $\mathrm{Li}$ et al. [26] to investigate the flotation kinetics of an inflatable cyclonic flotation column. They observed that the flotation rate of coarse and fine coal could be obviously improved by increasing the inflation rate. The reflux flotation cell, which permits throughput rates well beyond conventional flotation standards, was used to clean the coal [27].

Although the abovementioned studies reported promising results, only a few studies on the optimization of flotation reagents have been carried out. In the present study, the tailing samples were subjected to a flotation process to obtain a final clean product. The effects of several variables such as pulp concentration, inflation rate, kind of collectors, octanol dosages, revolving speed, flotation flow-sheets, and depressant dosages on the flotation performance were determined. More importantly, the improvement in the flotation technology of coal tailings will improve the economic value of tailings and reduce environmental pollution.

\section{Materials and Methods}

\subsection{Materials}

The coal sample used in this study was obtained from the flotation tailings of Zhaogu Coal Preparation Plant located in Henan province, China. Zhaogu Coal Preparation Plant began production in May 2009, and its designed production capacity was 6.0 Mt/a. A shallow slot heavy medium separator was used for primary and secondary cleaning of lump coal, and a three-product heavy media cyclone was used for the separation of fine coal. However, the normal production of the coal preparation plant was seriously affected by high ash and moisture content, low calorific value, and poor economic value. Therefore, the mineral composition of the tailings sample was analyzed by $X$-ray diffraction. A flotation machine (XFD 0.5 L/XFD 1.0 L, Jilin Exploration Machinery Plant, Changchun, China), an X-ray diffractometer (Quant'X Energy Dispersion, American Thermo Corporation, Waltham, Ameicia), and a scanning electron microscope (Zeiss Gemini SEM field emission type, Germany Zeiss Corporation, Oberkochen, Germany) were used in the experiments. The main flotation reagents used in the study, including collectors, frother, and depressants, are listed in Table 1. The collectors were labeled as C1, C2, C3, and C4. Octanol was used as the frother, and sodium hexametaphosphate, sodium silicate, sodium polyphosphate, and corn starch were used as depressants, respectively. 
Table 1. Main reagents used in the study.

\begin{tabular}{|c|c|c|c|c|}
\hline Reagent Names & Chemical Formula & Purity & Usage & Abbreviation \\
\hline $\begin{array}{c}\text { Diesel oil } \\
\text { Kerosene } \\
9883 \\
88050\end{array}$ & $\begin{array}{l}\text { Hydrocarbon } \\
\text { mixtures }\end{array}$ & Industrial & $\begin{array}{c}\text { Collector } \\
\text { (insoluble in water, soluble } \\
\text { in organic solvents) }\end{array}$ & $\begin{array}{l}\text { Collector } 1 \text { (C1) } \\
\text { Collector } 2 \text { (C2) } \\
\text { Collector } 3 \text { (C3) } \\
\text { Collector } 4 \text { (C4) }\end{array}$ \\
\hline Octanol & $\mathrm{C}_{8} \mathrm{H}_{18} \mathrm{O}$ & Chemically Pure & $\begin{array}{c}\text { Frother } \\
\text { (insoluble in water, soluble } \\
\text { in organic solvents) }\end{array}$ & - \\
\hline $\begin{array}{c}\text { Sodium } \\
\text { Hexametaphosphate }\end{array}$ & $\left(\mathrm{NaPO}_{3}\right)_{6}$ & Analytical Pure & $\begin{array}{c}\text { Depressant } \\
\text { (Soluble in water, insoluble } \\
\text { in organic solvents) }\end{array}$ & - \\
\hline Sodium Silicate & $\mathrm{Na}_{2} \mathrm{SiO}_{3} \cdot 9 \mathrm{H}_{2} \mathrm{O}$ & Analytical Pure & $\begin{array}{c}\text { Depressant } \\
\text { (Water-soluble silicate) }\end{array}$ & - \\
\hline Sodium Polyphosphate & $\begin{array}{c}\mathrm{Na}_{(n+2)} \mathrm{P}_{n} \mathrm{O}_{3 n+1} \\
n=2 \sim 6\end{array}$ & Analytical Pure & $\begin{array}{l}\text { Depressant } \\
\text { (Soluble in water) }\end{array}$ & - \\
\hline Corn starch & $\begin{array}{c}\left(\mathrm{C}_{6} \mathrm{H}_{10} \mathrm{O}_{5}\right)_{n} \\
n=300-1000\end{array}$ & Chemically pure & $\begin{array}{c}\text { Depressant } \\
\text { (strong adsorption } \\
\text { with mineral surface) }\end{array}$ & - \\
\hline
\end{tabular}

\subsection{Experimental Methods}

\subsubsection{Roughing Test}

The coal sample was first agitated in a 1.0-L flotation cell for $2 \mathrm{~min}$, after which the required dosage of the collector was added. The pulp was conditioned for $2 \mathrm{~min}$ and then octanol was added. After $0.5 \mathrm{~min}$, air was introduced, and froth samples were collected for $3 \mathrm{~min}$. The foam was marked as a concentrate, and the material that remained in the tank was marked as tailings. The concentrate and tailings were separately filtered, dried, and weighed, and their yield and ash were calculated and analyzed. The roughing flotation flow is shown in Figure 1.

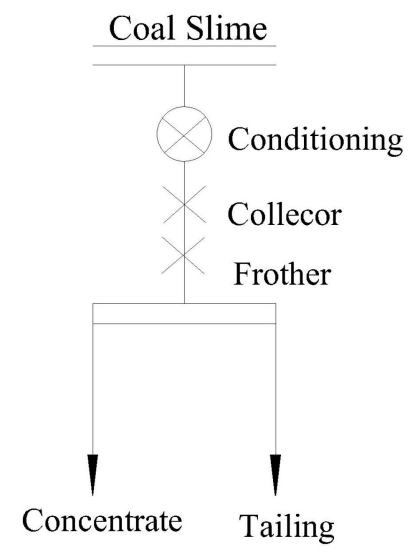

Figure 1. Roughing test flow chart.

\subsubsection{Roughing and Concentration}

The coal sample was first agitated in a 1.0-L flotation cell for $2 \mathrm{~min}$, after which the required dosage of the collector was added. The pulp was conditioned for $2 \mathrm{~min}$, and then octanol was added. After $0.5 \mathrm{~min}$, air was introduced, and froth samples were collected for $3 \mathrm{~min}$. The material left in the tank was marked as tailing 1 . The foam product was poured into a 0.5 -L flotation cell, and the pulp volume was adjusted to $0.5 \mathrm{~L}$ by adding deionized water. After stirring for $2 \mathrm{~min}$, air was introduced, and the froth sample was collected for $3 \mathrm{~min}$. Subsequently, the foam was marked as concentrate. The product left in the tank was marked as tailing 2. Tailings 1 and 2 were mixed and used as the final tailing. The roughing and concentration flow is shown in Figure 2. 


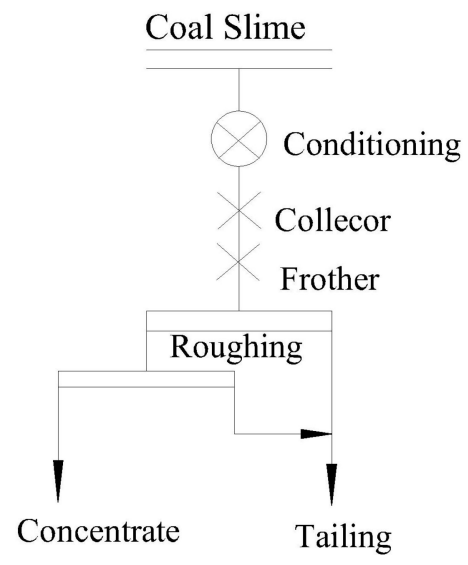

Figure 2. Roughing and concentration flow chart.

\subsubsection{Roughing and Concentration Test with Addition of Depressant}

The coal sample was first agitated in a 1.0-L flotation cell for $2 \mathrm{~min}$, after which the required dosage of the depressant was added. The pulp was conditioned for $3 \mathrm{~min}$, and the collector and frother were added and stirred for $2 \mathrm{~min}$ and $0.5 \mathrm{~min}$, respectively. Air was introduced, and the foam sample was collected for $3 \mathrm{~min}$. The product left in the tank was marked as tailing 1 . Subsequently, the foam product was poured into a $0.5-\mathrm{L}$ XFD flotation cell, and the pulp volume was adjusted to $0.5 \mathrm{~L}$ by adding deionized water. After stirring for $2 \mathrm{~min}$, air was introduced, and the froth samples were collected for $3 \mathrm{~min}$. The overflow foam product was marked as concentrate. The product left in the tank was marked as tailing 2. Subsequently, tailings 1 and 2 were mixed and used as the final tailing product. The flotation flow is shown in Figure 3.

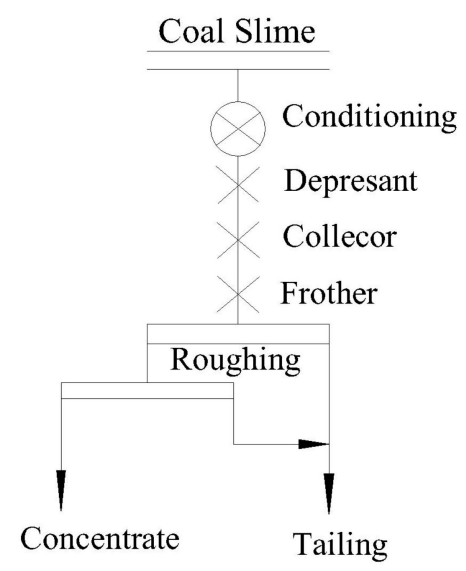

Figure 3. Flowchart of roughing and concentration with addition of inhibitor.

\section{Results}

\subsection{Analyses of Tailings}

The X-ray diffraction results are shown in Figure 4. As seen, the main gangue minerals of the samples were quartz and fraipontite. Quartz, however, dominated the mineral composition with characteristics such as soft texture, easy sliming, high adsorption ability, and the ability to easily pollute the clean coal $[28,29]$. 


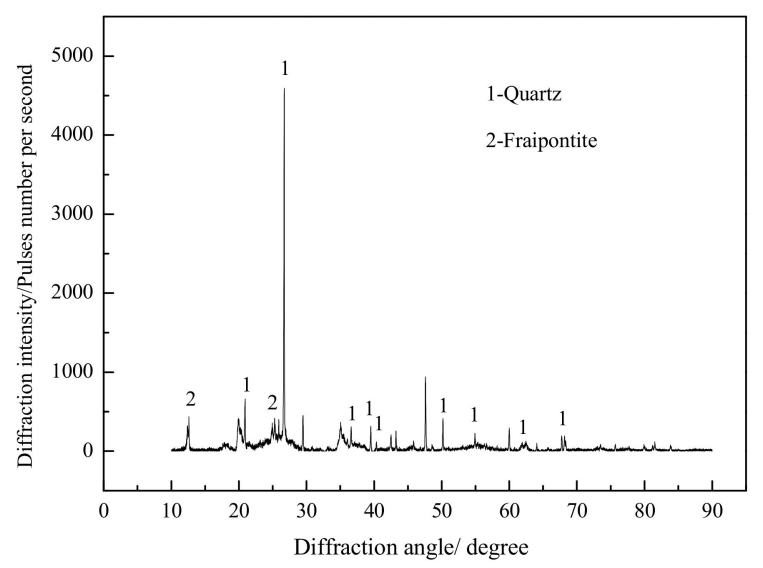

Figure 4. X-ray diffraction patterns of coal tailings.

The size distribution of the tailings is shown in Table 2.

Table 2. Size distribution analysis of the coal sample (\%).

\begin{tabular}{ccccccc}
\hline \multirow{2}{*}{ Size $(\mu \mathrm{m})$} & \multirow{2}{*}{ Yield } & \multirow{2}{*}{ Ash Content } & \multicolumn{2}{c}{ Cumulative Oversize } & \multicolumn{2}{c}{ Cumulative Undersize } \\
\cline { 4 - 7 } & & & Yield & Ash Content & Yield & Ash Content \\
\hline+500 & 3.48 & 63.16 & 3.48 & 63.16 & 100 & 62.01 \\
-500 to +300 & 4.26 & 42.56 & 7.74 & 51.82 & 96.52 & 61.97 \\
-300 to 175 & 7.79 & 32.86 & 15.53 & 42.31 & 92.26 & 62.86 \\
-175 to +75 & 10.39 & 33.72 & 25.92 & 38.87 & 84.47 & 65.63 \\
-75 & 74.08 & 70.11 & 100 & 62.01 & 74.08 & 70.11 \\
Totals & 100.00 & 62.01 & & & & \\
\hline
\end{tabular}

Based on the results presented in Table 2, it can be seen that the ash content of each size fraction was high, and the total ash content of raw coal was $62.01 \%$. As the particle size decreased, the ash content first decreased and then increased. The ash content of the size fraction from $-300 \mu \mathrm{m}$ to $175 \mu \mathrm{m}$ was the lowest with a value of $32.86 \%$. The ash content peaked at $70.11 \%$ for $-75 \mu \mathrm{m}$, which was $31.24 \%$ higher than that of the $+75 \mu \mathrm{m}$ size fraction. This, therefore, indicated that a large amount of fine mud existed in the fine size fraction $(-75 \mu \mathrm{m})$. However, fine mud pollutes clean coal easily during flotation through mechanical entrainment and coating [30]. Furthermore, the weight of the $-75 \mu \mathrm{m}$ size fraction accounted for $74.08 \%$ of the total. The ash content of the coal sample was high, and the size was fine and had to be purified by flotation [31].

\subsection{Effect of Pulp Concentration}

Pulp concentration had a significant influence on coal flotation. Low concentration results in a decrease in the processing capacity of the flotation equipment, and an increase in reagent dosage and electricity consumption. However, high pulp concentration may improve the ash content of clean coal. The inflation rate was $0.25 \mathrm{~m}^{3} /\left(\mathrm{m}^{2} \cdot \mathrm{min}\right)$, the revolving speed was $1800 \mathrm{rpm}, \mathrm{C} 1 \mathrm{was} 300 \mathrm{~g} / \mathrm{t}$, and octanol was $500 \mathrm{~g} / \mathrm{t}$. The flotation result is shown in Figure 5 . It can be seen from Figure 5 that when the pulp concentration was $100 \mathrm{~g} / \mathrm{L}$, the ash content of clean coal (12.21\%) was the lowest. 


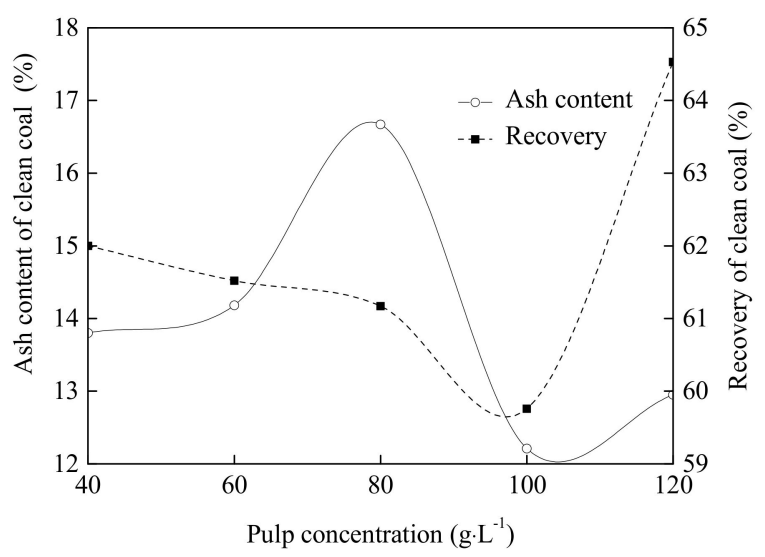

Figure 5. Effect of pulp concentration on flotation performance.

\subsection{Effect of Inflation Rate}

The inflation rate had a great impact on flotation performance. Moreover, the pulp concentration was $100 \mathrm{~g} / \mathrm{L}, \mathrm{C} 1$ dosage was $300 \mathrm{~g} / \mathrm{t}$, and octanol dosage was $500 \mathrm{~g} / \mathrm{t}$. The effect of the inflation rate is shown in Figure 6. As seen, the changes in the ash content with the inflation rate were contrary to the recovery. More gangue particles floated in the flotation process with the increase of inflation rate, thereby causing a contrary tendency [32]. When the inflation rate was $0.25 \mathrm{~m}^{3} /\left(\mathrm{m}^{2} \cdot \mathrm{min}\right)$, the ash content of clean coal $(12.57 \%)$ was the lowest, with a recovery of $64.62 \%$.

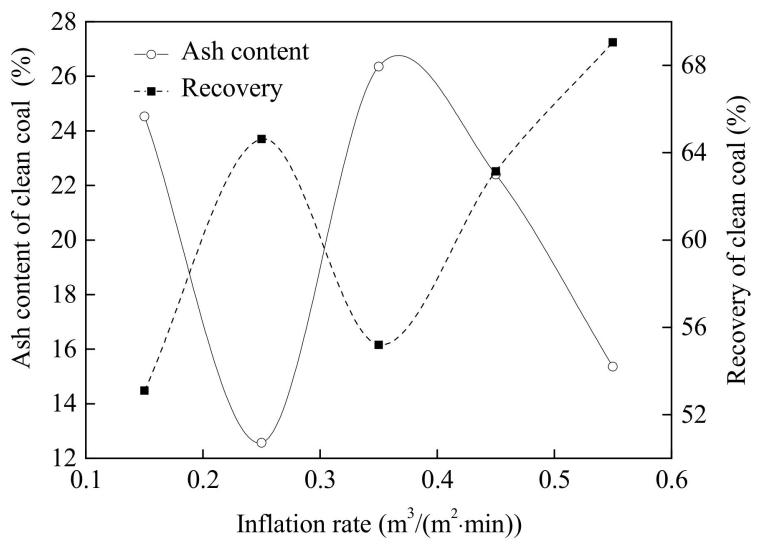

Figure 6. Effect of inflation rate on flotation performance.

\subsection{Effect of Combined Collectors}

Selectivity and collectivity are two important indicators of collectors. C1 and C2 are the nonpolar hydrocarbon oil collectors that are frequently used in coal preparation plants, and C3 and C4 are two new collectors. In order to improve the flotation performance of fine coal, the four collectors were combined, and their compositions are listed in Table 3. The pulp concentration was $100 \mathrm{~g} / \mathrm{L}$, the inflation rate was $0.25 \mathrm{~m}^{3} /\left(\mathrm{m}^{2} \cdot \mathrm{min}\right.$ ), the frother (octanol) dosage was $500 \mathrm{~g} / \mathrm{t}$, and the total collector dosage was $300 \mathrm{~g} / \mathrm{t}$. The effect of the collectors on flotation performance is shown in Figure 7. It can be seen that when C4 was used as the collector, the ash content of clean coal (14.03\%) was the lowest, with a recovery of $68.63 \%$. 
Table 3. Flotation conditions of collector tests.

\begin{tabular}{cccc}
\hline No. & Collector & No. & Collector \\
\hline 1 & C1 & 2 & C2 \\
3 & C 3 & 4 & C4 \\
5 & C3: C4 $=1: 1$ & 6 & C3: C2 $=1: 1$ \\
7 & C4: C2 $=1: 1$ & 8 & C1: C2 $=1: 1$ \\
9 & C3: C1 $=1: 1$ & 10 & C4: C1 $=1: 1$ \\
\hline
\end{tabular}

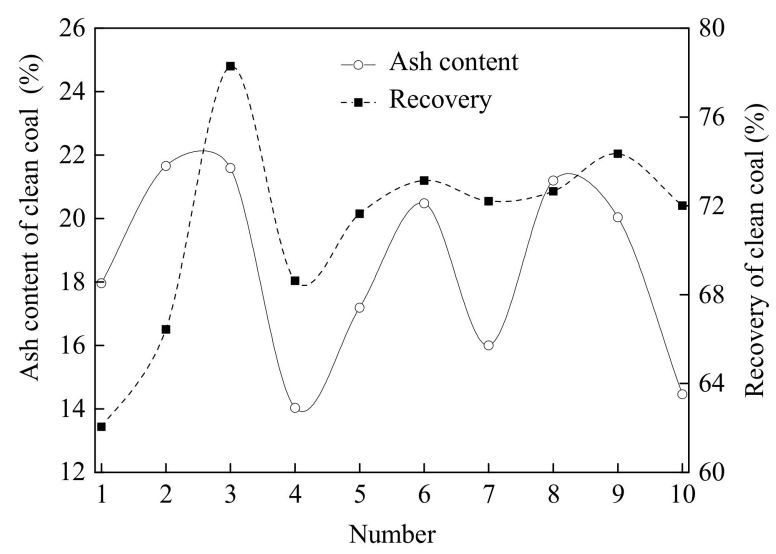

Figure 7. Effect of collectors on flotation performance.

Scanning electron microscope (SEM) photographs of the clean coal samples (Nos. 5-10 in Table 3) are presented in Figure 8. In sample 5, the coal particles and the reagent were not uniformly bound. The particle size of the coal particles was generally large, the fine mud was entrained, and the slime cover was severe. In sample 6, the coal particles and the chemical reagent were uniformly and tightly combined. Also, the coal particle size was small, the distribution was relatively uniform, the fine mud entrainment was small, and the cover was less. In sample 7, the distribution of the reagent on the surface of the coal particles was extremely uneven, and the reagents were concentrated on the surface of a small part of the coal samples. The symbiotic phenomenon of fine mud and coal particles was very serious, and the distribution of coal particles was not uniform. In sample 8, the fine mud entrainment was less, and the symbiosis between fine mud and coal particles was lighter. Sample 9 had a larger particle size and the reagent was evenly distributed on the surface of the coal particles. There was basically no fine mud cover or entrainment. In sample 10, the particle size of the coal was smaller, the reagent was distributed evenly, and some fine mud entrainment occurred.

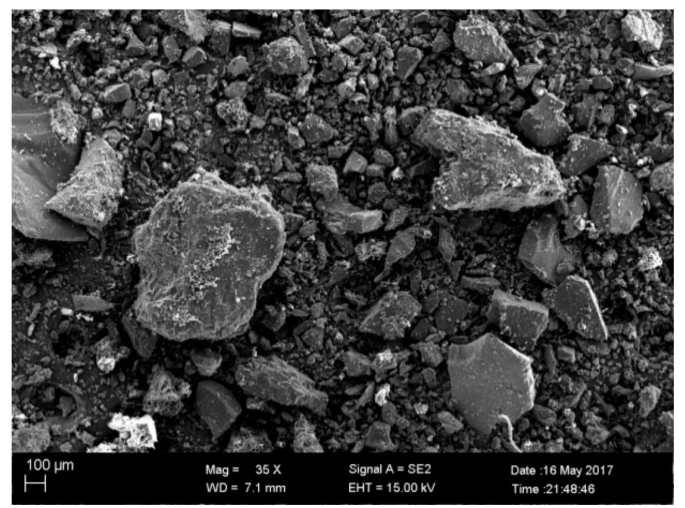

(a) No. 5

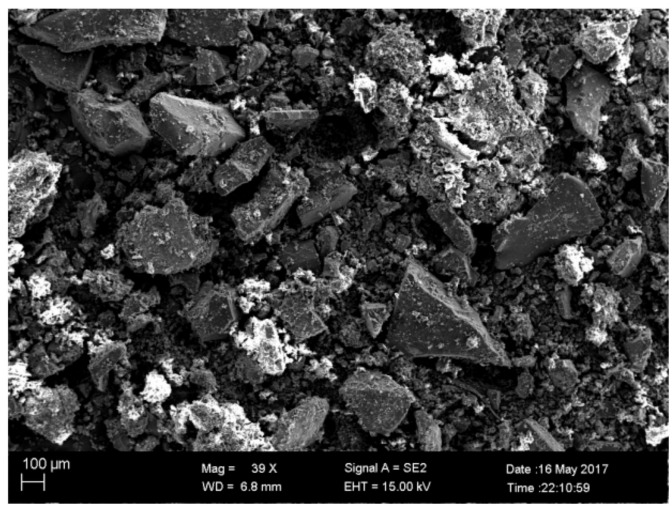

(b) No. 6

Figure 8. Cont. 


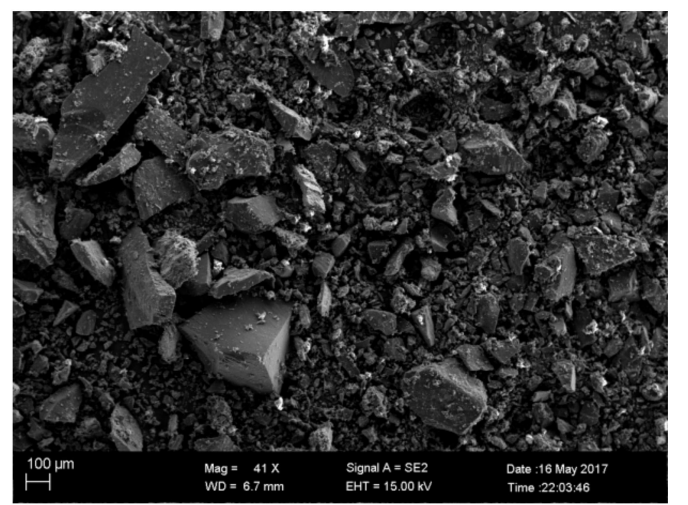

(c) No. 7

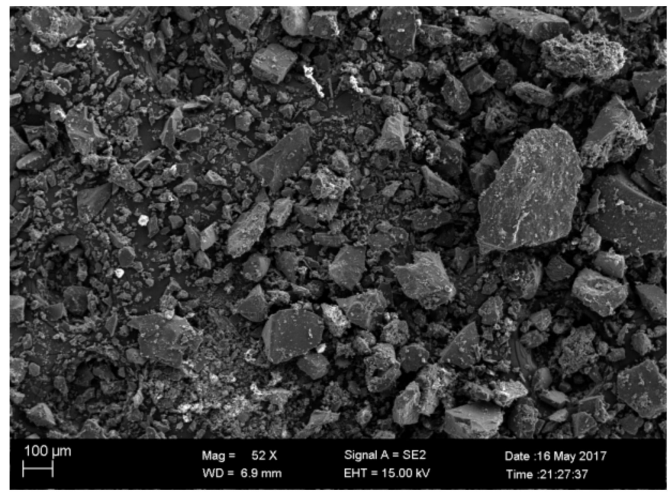

(e) No. 9

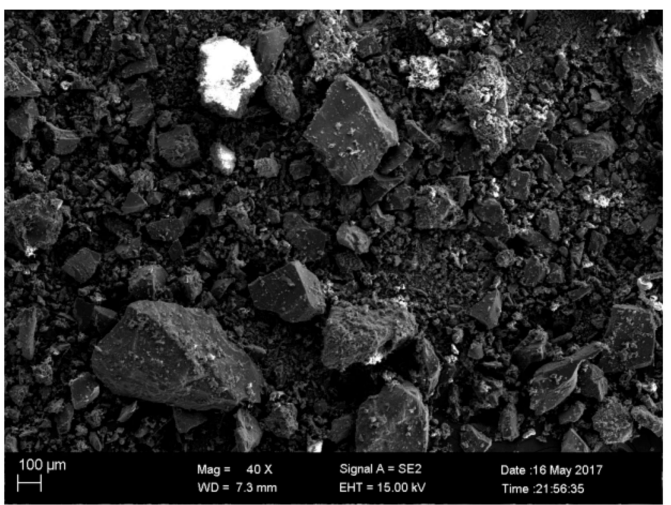

(d) No. 8

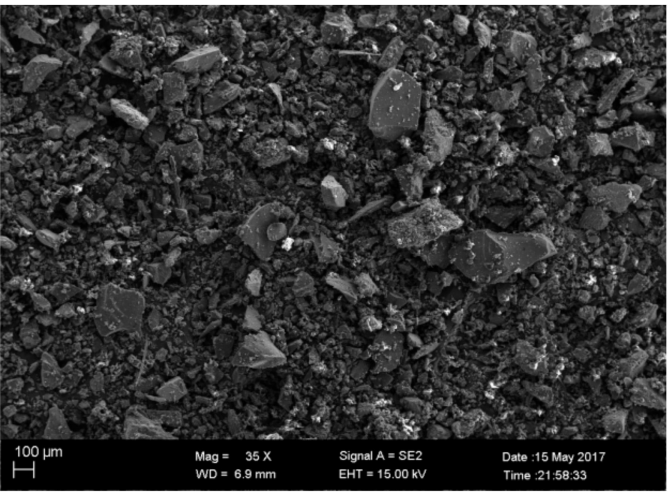

(f) No. 10

Figure 8. SEM of the clean coals of Nos. 5-10 in Table 3.

\subsection{Effect of Frother Dosages}

The inflation rate was $0.25 \mathrm{~m}^{3} /\left(\mathrm{m}^{2} \cdot \mathrm{min}\right)$, the pulp concentration was $100 \mathrm{~g} / \mathrm{L}$, the revolving speed was $1800 \mathrm{rpm}$, and C4 dosage was $300 \mathrm{~g} / \mathrm{t}$. The effect of frother (octanol) dosages is shown in Figure 9. As can be seen, as the frother dosage increased, the ash content and yield of clean coal first decreased and then increased. The flotation performance was best when the frother dosage was $500 \mathrm{~g} / \mathrm{t}$. The recovery and ash content of clean coal were $58.02 \%$ and $14.79 \%$, respectively.

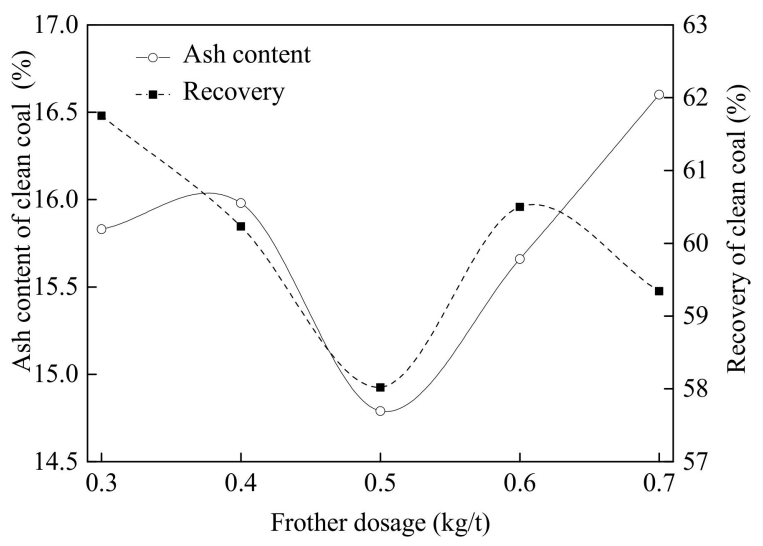

Figure 9. Effect of frother dosage on flotation performance.

\subsection{Effect of Revolving Speed}

The revolving speed of the impeller had an influence on the turbulence intensity of the pulp, which affected the collision probability of mineral particles and bubbles [33]. The inflation rate was 
$0.25 \mathrm{~m}^{3} /\left(\mathrm{m}^{2} \cdot \mathrm{min}\right)$, the pulp concentration was $100 \mathrm{~g} / \mathrm{L}$, the frother dosage was $500 \mathrm{~g} / \mathrm{t}$, and C4 dosage was $300 \mathrm{~g} / \mathrm{t}$. The effect of the revolving speed on flotation performance is shown in Figure 10. As can be seen, as the revolving speed increased, the ash of the clean coal slowly decreased at first, and then increased rapidly thereafter; the recovery kept increasing. The higher agitation speed (energy input) improved the flotability of difficult-to-float coal particles [34,35]. When the revolving speed was $2200 \mathrm{rpm}$, the flotation performance was best, with a recovery of $60.05 \%$ and an ash content of $14.64 \%$.

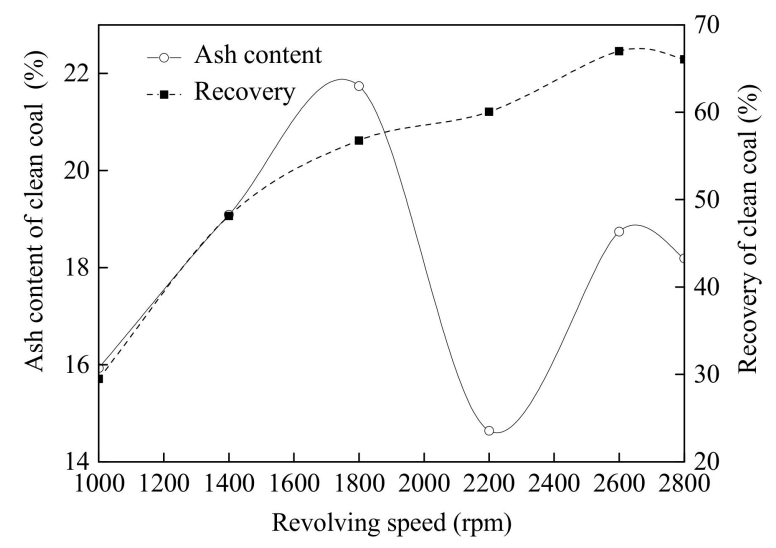

Figure 10. Effect of revolving speed on flotation performance.

\subsection{Roughing and Concentration with Addition of Depressants}

During the flotation process, clean coal can be contaminated by entrainment or covering of fine mud, with the flotation selectivity and the quality of clean coal being affected. In order to improve the flotation performance of coal washery tailings, depressants had to be added to the flotation process. Sodium hexametaphosphate, sodium silicate, sodium polyphosphate, and corn starch were used as depressants. The flotation flow chart is shown in Section 2.2. The inflation rate was $0.25 \mathrm{~m}^{3} /\left(\mathrm{m}^{2} \cdot \mathrm{min}\right)$, the pulp concentration was $100 \mathrm{~g} / \mathrm{L}$, the revolving speed was $2200 \mathrm{rpm}, \mathrm{C} 4$ dosage was $300 \mathrm{~g} / \mathrm{t}$, and the octanol dosage was $500 \mathrm{~g} / \mathrm{t}$. The flotation conditions of depressant tests are listed in Table 4 and the results of different depressants are listed in Figure 11.

Table 4. Flotation conditions of depressant tests.

\begin{tabular}{cccc}
\hline No. & Depressants & No. & Depressants \\
\hline 1 & Sodium hexametaphosphate & 2 & Sodium silicate \\
3 & Sodium polyphosphate & 4 & Corn starch \\
\hline
\end{tabular}

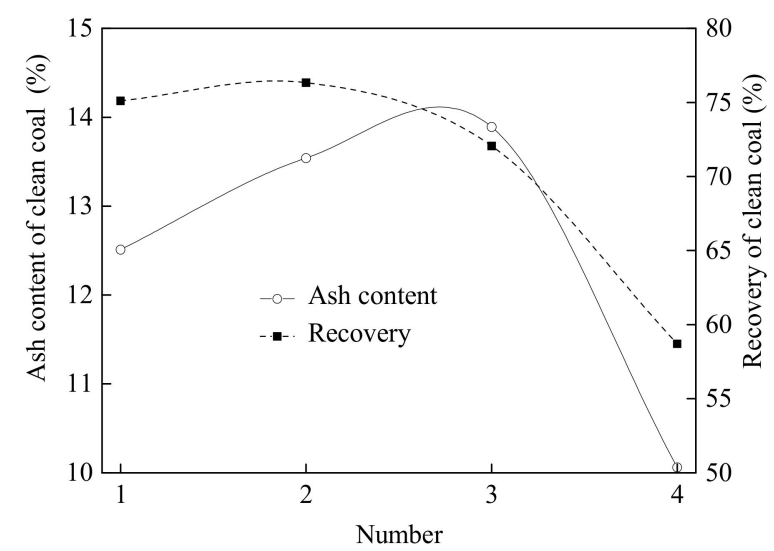

Figure 11. Flotation results of different depressants. 
It can be seen from Figure 11 that when sodium hexametaphosphate was used as the depressant, the flotation performance was the best, with a recovery of clean coal of $75.11 \%$ and an ash content of $12.51 \%$.

Sodium hexametaphosphate is a polyphosphate that can effectively inhibit alkaline earth metals, such as calcite and limestone. It also has good inhibition and dispersion effects on carbonaceous shale and mudstone gangue. The result of the depressant dosages is shown in Figure 12. As can be seen, as the dosage of sodium hexametaphosphate increased, the yield and recovery of clean coal first increased and then decreased, and the ash content of clean coal first decreased and then increased. The electronegativity of the mineral surface increased after the adsorption of sodium hexametaphosphate. The electronegative minerals repelled each other, and the effect of fine mud on flotation performance was reduced. When the amount of sodium hexametaphosphate was insufficient, the depressing effect was poor, and fine mud was easily entrained in the clean coal. However, when the amount of sodium hexametaphosphate was in excess, more fine mud could be adsorbed, and the flotation performance was affected. When the amount of sodium hexametaphosphate was $4 \mathrm{~kg} / \mathrm{t}$, the flotation performance was the best, and the recovery of clean coal was $71.88 \%$, and the ash content was $10.64 \%$. The ash content was reduced by about $4 \%$ and the recovery of clean coal was improved compared with using no depressant.

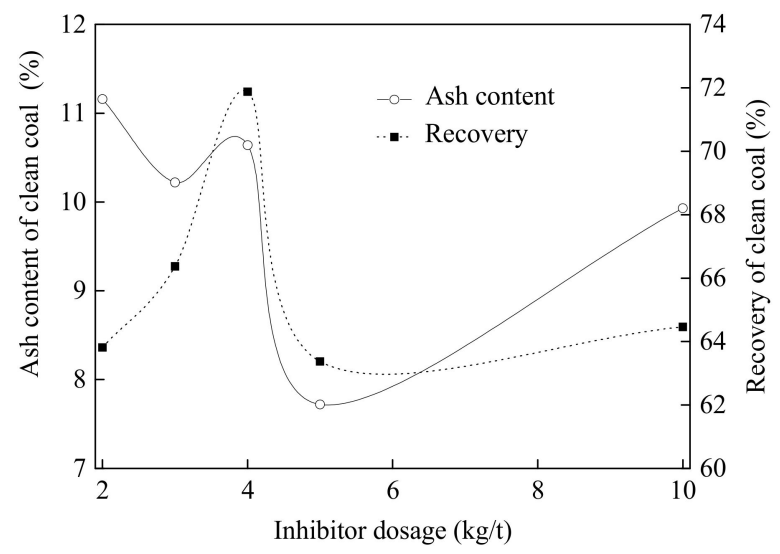

Figure 12. Flotation results of sodium hexametaphosphate dosages.

\section{Conclusions}

In the present work, the flotation performance of four different collectors was compared. The flotation flows were studied, and the mechanism of depressants was explored. The best flotation conditions were as follows: pulp concentration of $100 \mathrm{~g} / \mathrm{L}$, inflation rate of $0.25 \mathrm{~m}^{3} /\left(\mathrm{m}^{2} \cdot \mathrm{min}\right)$, collector (C4) dosage of $300 \mathrm{~g} / \mathrm{t}$, frother dosage of $500 \mathrm{~g} / \mathrm{t}$, and revolving speed of $2200 \mathrm{rpm}$. When the amount of sodium hexametaphosphate was $4 \mathrm{~kg} / \mathrm{t}$, the flotation performance was the best with a feed ash content of $62.01 \%, 71.88 \%$ recovery of clean coal, and an ash content of $10.64 \%$. Thus, the ash content was reduced by about $4 \%$, which was an improvement compared with using no depressant. Therefore, concentration tests and addition of depressants are an effective way to deash.

Author Contributions: Funding acquisition, G.C.; project administration, G.C.; writing-review \& editing, G.C.; methodology, G.C.; formal analysis, C.S.; data curation, S.W.

Funding: This research was funded by the National Natural Science Foundation of China, grant number 51604097; Key Scientific and Technological Project of Henan Province Foundation for University, grant number 192102310462, 172102310680; Key Teacher by Henan Polytechnic University, grant number 2017XQG-12; Doctoral Foundation of Henan Polytechnic University, grant number B2015-13.

Conflicts of Interest: The authors declare no conflict of interest. 


\section{References}

1. Nyashina, G.; Legros, J.C.; Strizhak, P. Environmental Potential of Using Coal-Processing Waste as the Primary and Secondary Fuel for Energy Providers. Energies 2017, 10, 405. [CrossRef]

2. Ma, C.D.; Liu, J.Y.; Zhang, Q.J.; Chi, Y.; Li, L. Optimization of promoting effect of SDBS on low rank coal flotation utilizing based on response surface method. Clean Coal Technol. 2019, 25, 35-42.

3. Nyashina, G.; Strizhak, P. Impact of Forest Fuels on Gas Emissions in Coal Slurry Fuel Combustion. Energies 2018, 11, 2491. [CrossRef]

4. Xia, W.C.; Xie, G.Y.; Peng, Y.L. Recent advances in beneficiation for low rank coals. Powder Technol. 2015, 277, 206-221. [CrossRef]

5. $\quad$ Liang, D.S.; Xie, Q.; Li, G.S.; Cao, J.Y.; Zhang, J. Influence of heating rate on reactivity and surface chemistry of chars derived from pyrolysis of two Chinese low rank coals. Int. J. Min. Sci. Technol. 2018, 28, 613-619.

6. National Bueau of Statistic. China Statistical Yearbook. Available online: http://www.stats.gov.cn/tjsj/ndsj/ (accessed on 01 April 2019).

7. China Coal Industry Association released "2017 Coal Industry Development Annual Report". Available online: http://dadieng.com/en/news_info.php?pid=23\&id=495 (accessed on 17 October 2019).

8. Adiansyah, S.J.; Rosano, M.; Biswas, W.; Haque, N. Life cycle cost estimation and environmental valuation of coal mine tailings management. J. Sustain. Min. 2017, 16, 114-125. [CrossRef]

9. Nyashina, G.; Shlegel, N.; Vershinina, K.Y.; Strizhak, P.A. The industrial waste as part of coal-water slurry fuels. Energy Fuels 2018, 32, 11398-11410. [CrossRef]

10. Vershinina, K.Y.; Kuznetsov, G.V.; Strizhak, P.A. Ignition Characteristics of Coal-Water Slurry Containing Petrochemicals Based on Coal of Varying Degrees of Metamorphism. Energy Fuels 2016, 30, 6808-6816. [CrossRef]

11. Ni, C.; Xie, G.Y.; Jin, M.G.; Peng, Y.L.; Xia, W.C. The difference in flotation kinetics of various size fractions of bituminous coal between rougher and cleaner flotation processes. Powder Technol. 2016, 292, 210-216. [CrossRef]

12. Zhao, H.Y.; Li, Y.H.; Song, Q.; Liu, S.C.; Yan, J.; Ma, Q.X.; Ma, L.; Shu, X.Q. Investigation on the thermal behavior characteristics and products composition of four pulverized coals: Its potential applications in coal cleaning. Int. J. Hydrog. Energy 2019, 44, 23620-23638. [CrossRef]

13. Kupka, N.; Rudolph, M. Froth flotation of scheelite-A review. Int. J. Min. Sci. Technol. 2018, 28, 373-384. [CrossRef]

14. Li, Y.G.; Li, J.W.; Chen, P.; Chen, J.Z.; Shen, L.J.; Zhu, X.N.; Cheng, G. The effect of ultra-fine coal on the flotation behavior of silica in subbituminous coal reverse flotation. Powder Technol. 2019, 342, 457-463. [CrossRef]

15. Bogacz, W.; Lemanowicz, M.; Gierczycki, A.; Mielanczyk, A. Flocculation of flotation tailings Using Thermosensitive Polymers. Chem. Process. Eng. 2017, 38, 379-392. [CrossRef]

16. Tozsin, G.; Acar, C.; Sivrikaya, O. Evaluation of a Turkish Lignite Coal Cleaning by Conventional and Enhanced Gravity SeparationTechniques. Int. J. Coal Prep. Util. 2018, 38, 135-148. [CrossRef]

17. Ding, Q.P.; Gui, X.H. Research Status of separation of high ash, difficult separated fine slime. Coal Eng. 2010, 57, 29-31.

18. Gui, X.H.; Cheng, G.; Liu, J.T.; Li, S.L.; Wang, Y.T.; Cao, Y.J. Process characteristics of heterogeneous fine mud in the coal flotation. J. China Coal Soc. 2012, 37, 301-309.

19. Yaşar, Ö.; Uslu, T.; Şahinoğlu, E. Fine coal recovery from washery tailings in Turkey by oil agglomeration. Powder Technol. 2018, 327, 29-42. [CrossRef]

20. Barraza, J.; Guerrero, J.; Piñeres, J. Flotation of a refuse tailing fine coal slurry. Fuel Process. Technol. 2013, 106, 498-500. [CrossRef]

21. Ren, R.C.; Zheng, Z.Y.; Sun, D.Z.; Cheng, G.B.; Dong, Q.G.; Zhao, J.Y. Upgrading of Refractory Tail Coal Through Grinding, Mine Classification and Flotation. Coal Convers 2019, 42, 72-77.

22. Shi, C.X.; Wang, Z.N.; Xie, G.Y. Study and application of the graded floatation technology of coal slime. Coal Eng. 2005, 52, 58-60.

23. Jiang, K.; Dickinson, J.E.; Galvin, K.P. Two-stage fast flotation of coal tailings using reflux flotation. Miner. Eng. 2016, 98, 151-160. [CrossRef] 
24. Netten, K.V.; Galvin, K.P. Rapid beneficiation of fine coal tailings using a novel agglomeration technology. Fuel Process. Technol. 2018, 176, 205-210. [CrossRef]

25. Li, Y.G.; Honaker, R.; Chen, J.Z.; Shen, L.J. Effect of particle size on the reverse flotation of subbituminous coal. Powder Technol. 2016, 301, 323-330. [CrossRef]

26. Li, N.B.; Li, Y.F.; Fu, X.Q.; Gao, F.L.; Zhang, C.Q.; Xia, W.C.; Liang, L. Flotation kinetics of coal in the Inflatable Cyclonic Flotation Column. Powder Technol. 2018, 335, 204-210. [CrossRef]

27. Dickinson, J.E.; Jiang, K.; Galvin, K.P. Fast flotation of coal at low pulp density using the Reflux Flotation Cell. Chem. Eng. Res. Des. 2015, 101, 74-81. [CrossRef]

28. Cheng, G.; Gui, X.H.; Liu, J.T.; Xu, H.X.; Wang, Y.T.; Zhang, Q.D.; Song, C.A. Study on Size and Density Distribution in Fine Coal Flotation. Int. J. Coal Prep. Util. 2013, 33, 99-116. [CrossRef]

29. Cheng, G.; Zhang, C.X.; Zhang, X.M.; Jia, K. Desulfurization of flue gas by means of lignite-derived potassium humate. Fuel 2019, 252, 646-652. [CrossRef]

30. Cheng, G.; Li, Z.Y.; Ma, Z.L.; Cao, Y.J.; Sun, L.J.; Jiang, Z.D. Optimization of collector and its action mechanism in lignite flotation. Powder Technol. 2019, 345, 182-189. [CrossRef]

31. Wang, B.; Peng, Y.J. The interaction of clay minerals and saline water in coarse coal flotation. Fuel 2014, 134, 326-332. [CrossRef]

32. Cheng, G.; Shi, C.L.; Yan, X.K.; Zhang, Z.J.; Xu, H.X.; Lu, Y. A study of bubble-particle interactions in a column flotation process. Physicochem. Probl. Miner. Process. 2017, 53, 17-33.

33. Yu, Y.X.; Cheng, G.; Ma, L.Q.; Huang, G.; Wu, L.; Xu, H.X. Effect of agitation on the interaction of coal and kaolinite in flotation. Powder Technol. 2017, 3353, 122-128. [CrossRef]

34. Cheng, G.; Yu, Y.X.; Ma, L.Q.; Xia, W.C.; Xu, H.X. Energy feature of a multi-flow column flotation process. Physicochem. Probl. Miner. Process. 2017, 53, 1264-1284.

35. Cheng, G.; Zhang, C.X.; Cao, Y.J.; Jiang, Z.D. Review of energy-consumption measuring techniques for the flotation process. Energy Sources Part A 2018, 40, 2367-2377. [CrossRef]

(C) 2019 by the authors. Licensee MDPI, Basel, Switzerland. This article is an open access article distributed under the terms and conditions of the Creative Commons Attribution (CC BY) license (http://creativecommons.org/licenses/by/4.0/). 